\title{
Sending Away Foreign Wives in Ezra 9-10: With a Brief Reflection from a Minority Tribal Perspective
}

\author{
Chingboi Guite PHAIPI \\ McCormick Theological Seminary, Chicago
}

\begin{abstract}
Ezra 9-10, commonly known as "intermarriage crisis" or "forced divorce of foreign wives," has attracted a wide variety of interpretations of the dismissal of foreign wives. Some of the proposed rationales include political, social, economic, and ethnic purity. Such rationales, while having their own merits, are not evidenced in the text. This article offers a literary reexamination of what the text portrays about the protagonist group's motivation to take such stringent action. The protagonist's strong self-perception is the main factor behind their negative perception of the antagonist "others" and thus its stringent resolution to deal with foreign wives. I also briefly reflect on what a minority Christian tribal today could do with such a strong biblical narrative.
\end{abstract}

\section{Keywords}

foreign wives, intermarriage, the "other," second temple, minority, tribal

\section{INTRODUCTION}

Ezra 9-10 is generally known for the sending away of foreign wives and their children. In the narrative of Ezra 9-10, the protagonist group is the golah (gôlâ) community (Ezr 9:4; 10:6,7,16), ${ }^{1}$ which is mainly formed of those

1 I will use the term in its transliterated form, golah, without translating it, for the following reasons. While certainly the term golah implies that the protagonist group is mainly made up of those who returned from the exile, the text does not explicitly state that it is comprised exclusively of those who returned. The text leaves it open as to whether those who would follow the golah's way of worship are included in the community, and in fact, it appears that even a golah community member runs the risk of being ejected if they fail to abide by the ways of the community, as we shall see 
who returned to Judah from the Babylonian exile. The narrative begins with a report that the golah community has failed to keep themselves apart from the peoples of the lands and that some golah men have even married foreign women (Ezr 9:1-2). The community then resolves to send away all the foreign wives and their children (10:3). Such a dramatic way of dealing with foreign wives is unimaginable to modern multicultural perspectives and raises critical questions such as what might have motivated such a stringent action, who might the foreign wives be, and what can a Christian minority community today do with such a strong biblical narrative.

The attempt to understand this biblical narrative has elicited a wide variety of interpretations. For instance, some propose political rather than cultic or religious reasons, ${ }^{2}$ others identify the so-called foreigners as simply non-exiled Jews, not real foreigners, ${ }^{3}$ some interpret the issue as that of returning migrants trying to protect their ethnic identity, ${ }^{4}$ and still others read the passage as Christian Scripture and interpret the sending away of foreign wives as a less harsh option than the stringent pentateuchal laws (such as Deuteronomy 7). ${ }^{5}$ Still others see the passage rather as an indication of acceptance, not rejection, of the foreign wives. ${ }^{6}$ These are just

in the analysis of the narrative. To maintain such nuances, I will use the term in its transliterated form, golah.

2 Wolfgang Oswald, "Foreign Marriages and Citizenship in Persian Period Judah," Journal of Hebrew Scriptures 12 (2012): 2-5. https://doi.org/10.5508/jhs.2012.v12.a6 (accessed February 12, 2020).

3 See, for example, Daniel L. Smith-Christopher, "The Mixed Marriage Crisis in Ezra 9-10 and Nehemiah 13: A Study of the Sociology of Post-Exilic Judaean Community," in Second Temple Studies, Vol. 2: Temple Community in the Persian Period, ed. Tamara C. Eskenazi and Kent H. Richards (Sheffield: JSOT Press, 1994), 257; Tamara Cohn Eskenazi and Eleanore P. Judd, "Marriage to a Stranger in Ezra 9-10," in Second Temple Studies, Vol. 2: Temple Community in the Persian Period, ed. Tamara C. Eskenazi and Kent H. Richards (Sheffield: JSOT Press, 1994), 266-285.

4 Katherine Southwood, Ethnicity and the Mixed Marriage Crisis in Ezra 9-10: An Anthropological Approach (Oxford: Oxford University Press, 2012).

5 Csilla Saysell, "According to the Law": Reading Ezra 9-10 as Christian Scripture (Winona Lake, IN: Eisenbrauns, 2012).

6 Such as: Yonina Dor, "The Rite of Separation of the Foreign Wives in EzraNehemiah," in Judah and the Judeans in the Achaemenid Period: Negotiating Identity in an International Context, ed. Oded Lipschits et al. (Winona Lake: Eisenbrauns, 2011), 174-186, and Sara Japhet, "The Expulsion of the Foreign Women (Ezra 9-10): The Legal Basis, Precedents, and Consequences for the Definition of Jewish Identity," in Sieben Augen auf einem Stein (Sach 3,9): Studien zur Literatur des Zweiten Tempels: 
a few examples to show how the Ezra 9-10 narrative has provoked a wide range of interpretations from a variety of fields. ${ }^{7}$ Each of these arguments has its own merits. But due to the lack of extra-textual evidence from the Persian period and the unspecific nature of the text of Ezra 9-10, the diverse interpretations lead to no consensus. We will see that most interpretations lack evidence, particularly from the text itself. In such a scenario, I offer a literary analysis of the text to re-examine what might have led the community to such a rigid resolution. This approach will demonstrate that the protagonist golah community perceives itself primarily as a cultic community—as the "holy seed" and the "remnant"—which compels them to maintain and carry forward that identity into the future. Such a staunch self-perception obliges them to remain apart from "other" people. The text does not give enough evidence to allow the foreign wives to be specifically identified, and the antagonist "other" people, designated as peoples of the lands and foreign women, should best be understood as encompassing any non-golah-non-exiled Jews or non-Jews-who do not comply with the golah community's cultic ways. The first task is to explore the characters and their characterizations in the narrative.

\section{Characters and Characterization in THE NARRATIVE}

There are two main characters in Ezra 9-10, namely, the protagonist golah group and the antagonist "other" people.

The golah group is identified by terms such as the golah (Ezra 9:4; 10:6, "sons" of the golah 10:7, 16), Israel (Ezr 9:1; 10:1, 2, 5), remnant (Ezr 9:8, 13, 14, 15), assembly (qāhāl) ("assembly of the golah," Ezr 10:8; "the entire assembly" Ezr 10:12, 14), "men" of Judah and Benjamin (Ezr 10:9). They are also presented as attentive and willing to obey YHWH ("those who tremble at the command of God," Ezr 9:4; "those who tremble at the command of our God," 10:3). From these designations, it can be seen that the protagonist group, the golah community, is defined as the remnant Israel, attentive and obedient to YHWH God.

Festschrift für Ina Willi-Plein zum 65 (Neukirchen-Vluyn: Neukirchener Verlag, 2007), 100, 151-161.

7 For a detailed survey of the arguments and rationales, see Southwood, Ethnicity and the Mixed Marriage Crisis in Ezra 9-10, 75-122. 
Unlike the protagonist group, the antagonist group in Ezra 9-10 is vaguely identified. They are designated by two terms-peoples of the land/s (peoples of the lands in Ezr 9:1, 2, 11; peoples of the land in 10:2,11) ${ }^{8}$ and foreign women (Ezr 10:2, 10, 11, 14, 17, 18, 44) with no further specific identification. Clearly, the narrative is primarily about the golah community, and "other" people are included only inasmuch as it aids in validating the golah group. For instance, if the "other" group is unclean, the golah group is clean. Evidently, how the golah group understands itself factors into their perception of "other," non-golah people.

\section{Self-perception of the Golah Community}

The narrative presents two ways in which the golah community understands itself - as the "holy seed" (Ezr 9:2) and as the "remnant" (Ezr 9:13-14):

[9:1-2] The people of Israel, the priests and the Levites have not kept themselves apart from the peoples of the lands, with their abominations like the Canaanites, the Hittites, the Perizzites, the Jebusites, the Ammonites, the Moabites, the Egyptians and the Amorites. For they have taken some of their daughters for themselves and their sons, and the holy seed has mixed itself with the peoples of the lands, and the hand of the leaders and rulers are foremost in this unfaithfulness.

[9:13-14] After all that came upon us because of our evil deeds and our great guilt, since you our God have punished us less than our iniquities deserved and have given us a remnant as this, shall we break your commandments again and intermarry with the peoples of these abominations? Would you not be angry at us until there is no remnant or survivor at all?

Holy Seed (zera' haqqōdeš)

The leaders who report to Ezra about their community's unfaithfulness state that the holy seed has been mixed with the peoples of the land (Ezr 9:2). Thus, one way they understand themselves is as the holy seed (Ezr 9:2). "Holy" (qōdeš) in the current context would best be understood in the sense

8 From how the terms are vaguely employed, the plural forms of peoples of the land $/ \mathrm{s}$ would simply be variants in the term and not a way to refer to different groups of people. The variant forms could indicate two separate authors, but would still largely refer to the same people. Lisbeth S. Fried, Ezra: A Commentary (Sheffield, England: Sheffield Phoenix Press, 2015), 392. 
of being set apart for YHWH or belonging to YHWH. ${ }^{9}$ Understanding the term as "being set apart" fits their expectation to "keep themselves apart" from the peoples of the lands (9:1). The overriding theme of the book of Ezra is also that the golah group is a group "set apart," meant not to mingle with "other" people (Ezr 3:3; 4:3; 6:21). The golah community is often evaluated by whether or not they have "kept themselves apart from the people/s of the land/s" (Ezr 6:21; 9:1). Thus, from a literary point of view, the term "holy" in Ezra has the sense of being set apart from "others," set apart for YHWH.

Outside of Ezra, too, the term "holy" (qōdeš) means "being set apart." For example, when the priests are said to be holy, it designates their relation to YHWH (Ex 28:36; 39:30; Lv 21:6). In Jeremiah 2:3, the Israelites are holy to YHWH, thus set apart as the first fruits of YHWH's harvest. In Isaiah 62:12 Israel is holy for YHWH, that is, set apart as redeemed by YHWH. Being set apart also comes with the obligation to maintain that status-for instance, the Israelites are to maintain a ritual diet as they are set apart for YHWH (Ex 22:30). In other words, holiness is not an innate or immutable condition, but response and maintenance of that status is necessary. ${ }^{10}$

The term "seed" (zera) refers to offspring or descendants and is thus oriented toward the future. For instance, the seed of woman (Eve) refers to future humankind ( $\mathrm{Gn} 3: 15$ ), the seed of the patriarchs refers to their descendants (Ex 32:13; 33:1; Jo 24:3), seed of Abraham refers to Israelites (Is 41:8; Ps 105:6; Jer 33:26; 2 Chr 20:7). In the context of Ezr 9:2, the term "seed" is used as a self-designation for the golah community, implying that they understand themselves as the descendants of pre-exilic Israel (Ezr 9:613). As there is no mention of people who were not exiled and remained in the land, they are apparently included with the "other," peoples of the

9 One of the meanings of "holy" is to be consecrated, to be set apart. BDB 871-872, The Dictionary of Classical Hebrew, Vol. 7: 198-199. Following Clines's examination of all occurrences of the root qdš in the Hebrew Bible and their usage/meaning in those contexts, it is also observed that the term implies "belonging to God." David J. A. Clines, Alleged Basic Meanings of the Hebrew Verb Qdš 'Be Holy': An Exercise in Comparative Hebrew Lexicography. https://www.academia.edu/28065748/Alleged_ Basic_Meanings_of_the_Hebrew_Verb_qd\%C5\%A1_be_holy_An_Exercise_in_ Comparative_Hebrew_Lexicography. (accessed December 10, 2019).

10 Hannah K. Harrington, "Interpreting Leviticus in the Second Temple Period: Struggling with Ambiguity," in Reading Leviticus: A Conversation with Mary Douglas, ed. John F.A. Sawyer (Sheffield: Sheffield Academic, 1996), 215. 
lands. Thus, it appears that the golah group sees themselves exclusively as the continuation of the pre-exilic Israel.

The only other place in the Hebrew Bible in which "holy" and "seed" appear together as a phrase "holy seed" is Isaiah 6:13, where the phrase represents a rebirth of life. ${ }^{11}$ Even after the tree has fallen, the stump remains that will sprout again; that is, even after near total destruction or exile, the stump of Israel, the "holy seed," remains and will revive as a faithful remnant, a new creation of God. ${ }^{12}$ Thus, even after a widespread destruction of cities and of social and political institutions and Israel had left its own land, there is still hope for survival and the revival of a remnant, a holy seed that will spring up from the stump. ${ }^{13}$ There is hope for renewal beyond judgment. ${ }^{14}$ Such is the self-understanding of the golah community in Ezra 9-10 as seen in Ezra's prayer, that though they have transgressed, God saved them as a remnant and there is still hope for revival (Ezr 9:8; $10: 2 b)$.

As Becking rightly points out, the term "holy seed" as a radical selfinterpretation of the golah group as being saved by God entails that they cannot be defiled by foreign elements. ${ }^{15}$ Becking asserts that the term really is a combination of two traditional depictions of Israel-Israel called a "holy nation" in Deuteronomy and the "seed of Abraham" elsewhere. As discussed above, the golah group highlighted their continuity with pre-exilic Israel ("seed of Abraham") and how they have to set themselves apart for YHWH ("holy nation").

In sum, the golah community understands itself as a "holy seed"-a community set apart for YHWH, set apart from others. This understanding defines the core criterion for membership as to "have kept oneself separated from the people/s of the land/s" (Ezr 9:1). This self-understanding of the

11 While there are textual difficulties, we can make sense out of it. The text is thus commonly understood to present an element hope and renewal. See, for instance, Brevard S. Childs, Isaiah, 1st ed. (Louisville, KY: Westminster John Knox Press, 2001), 58; J.J.M. Roberts, First Isaiah. A Commentary (Minneapolis: Fortress, 2015), 101.

Childs, Isaiah, 54-59.

John D.W. Watts, Isaiah 1-33, 2 vols., WBC 24 (Waco, TX: Word Books, 1985), 109110 .

4 Roberts, First Isaiah, 101.

Bob Becking, “On the Identity of the 'Foreign' Women in Ezra 9-10," in Exile and Restoration Revisited: Essays on the Babylonian and Persian Periods in Memory of Peter R. Ackroyd, ed. Gary N. Knoppers et al. (London: T\&T Clark, 2009), 32. 
golah community as "set apart for YHWH" also correlates with their selfunderstanding of being a "remnant saved by YHWH."

Remnant (pĕlêtâ)

The golah community also understands themselves as the remnant (Ezr 9:8, 13, 14, 15). Ezra rhetorically states in his prayer how the golah community would still act unfaithfully by marrying those who followed abominable practices even after being saved as a remnant (Ezr 9:13, 14).

The term "remnant" has a salvific underpinning referring back to the rescuing of Israelites and Judeans in the larger catastrophe of Judah and Israel. Being left, spared, or saved as a remnant is a concept for future survival. The usages of the term outside of Ezra also confirm that those left as "remnant" are not left or spared randomly but are saved purposefully by YHWH. For instance, in 2 Kings 19:30 (=Is 37:31-32), the remnant Judah will take root below and bear fruit above. In Jeremiah 50:20, YHWH declares that those spared will be pardoned. In Judges 21:17, a remnant will be there so that the tribe of Benjamin may not be blotted out. Joel 3:5 states that those who invoke the name of YHWH shall escape and be a remnant on Mount Zion and in Jerusalem. In Jeremiah 44:14, many will not survive the sword, famine, and pestilence, but a small remnant will return to Judah. Isaiah 10:20-23 speaks of a small remnant of Israel that survives destruction and will lean on none other than YHWH. In Isaiah 4:2-3, a remnant left in Zion and in Jerusalem will be called holy. The concept of an Israelite remnant is then not limited to escapees from religious or political struggles, but it also secures the future existence of the people after a breakdown: a remnant of people faithful to YHWH, representing the true Israel. ${ }^{16}$ Thus, the term "remnant," though it may be used in different contexts to refer to different people, has the connotation of being purposefully spared by the mercy of YHWH.

It is not possible to specify from which reference/s Ezra 9-10 borrows its usage of the term "remnant." It is clear, however, that in Ezra 9-10 it refers to the golah community, and no reference is made of those who remained

16 Hasel, "pẹlêțâ," Theological Dictionary of the Old Testament, Vol. 11, ed. G. Johannes Botterweck, Helmer Ringgren, and Heinz-Josef Fabry (Grand Rapids: Eerdmans, 2000), 563. 
in the land. ${ }^{17}$ As a remnant, then, the golah community understands itself as a small portion saved out of widespread destruction to begin a new life dependent on YHWH. Surviving destruction also implores firmer loyalty to YHWH and the Torah in order to sustain their remnant status. Ezra recounts how YHWH God has granted them to be a remnant and also has given them a stake in his holy place, even after all they have suffered because of their iniquities (9:8; also 9:13, 14, 15).

Being also given a "stake" (yātèd) implies some kind of stability or security for the golah community, at least for a brief moment, through the rebuilding of the temple (Ezr 9:8). ${ }^{18}$ But being given a stake also expresses vulnerability and dependence on YHWH, as Moffat argues. ${ }^{19}$ In the context of Ezra 9-10, the golah community is in a vulnerable situation because of their unfaithfulness, and Ezra's prayer clearly points to the imminent danger of YHWH's wrath faced by the community because of intermarriage (Ezr 9:6-15). First, that "stake" has been given for just a moment. Second, that security is dependent solely on YHWH, as it is only by YHWH's mercy and favor that such a stake has been given. Now that they have failed to keep apart from the "other" despite being spared as a remnant and given a stake, they could easily lose that favor too (9:14). Thus, being spared as

17 Generally, postexilic literature tends to view the remnant as centered in Babylon, that is, those exiled to Babylon who then later returned to Judah, and Jerusalem is viewed as the periphery. On the other hand, pre-exilic literature centers the remnant on Jerusalem and view Babylon as the periphery. Dalit Rom-Shiloni, Exclusive Inclusivity: Identity Conflicts between the Exiles and the People Who Remained (6th-5th Centuries BCE) (New York: Bloomsbury, 2013), 87-89.

18 The metaphor of the "stake (or tent peg) in holy place" can be understood in two ways. First, in a nomadic way of life, a secure tent peg meant stability for the tent and thereby the occupants (Is 54:2). Second, it can also be understood in how a person is compared to a peg fixed in a firm place and said to be able to hold the whole family together (Is 22:23). H. G. M. Williamson, Ezra, Nehemiah, WBC 16 (Waco, TX: Word Books, 1985), 135.

19 Moffat argues how the "stake" speaks more of insecurity or vulnerability than of firm security. He argues that while the stake/peg metaphor in Isa 22 can indeed mean firmness or security, the context is more of the vulnerability of the peg, as the peg on which the family of Eliakim holds on to will fall once the Divine cut its off (Is 22:2325). Donald P. Moffat, "The Metaphor at Stake in Ezra 9:8," Vetus Testamentum 63, no. 2 (2013): 290-298, https: / / doi.org/10.1163/15685330-12341111 (accessed January 20, 2020). In a similar manner, the "stake" of the golah community is fully dependent on YHWH, and it could fall if they continue to act unfaithfully toward YHWH. 
a remnant and given a stake comes with responsibilities, and they cannot afford to do what would not be acceptable to YHWH.

The two self-conceptions of the golah community that are presented in the text-a holy seed $(9: 2)$ and a remnant $(9: 8,13,14,15)$-are interconnected. Both concepts understand the community as one that is set apart for YHWH to continue the community as the true Israel through absolute loyalty and obedience to YHWH. This self-perception of the community frames their view toward "other" people, and subsequently, the stringent view on intermarriage would have come preeminently from their desire to maintain their status of being set apart for YHWH and a remnant to continue Israel into the future.

\section{Who Are the "Other"?}

The designations of the "other"-peoples of the lands (Ezr 9:1, 2, 11), peoples of the land $(10: 2,11)$ and foreign women $(10: 2,10,11,14,17,18,44)$ are without further specific identification for the terms.

People/s of the Land/s

Some argue that the peoples of the land/s are not really "other" but simply those Jews who did not go into exile; thus the issue would involve inner-Yehudite conflicts, ${ }^{20}$ while others argue that there is no evidence of inter-Yehudite conflicts. ${ }^{21}$ In response to these opposing views, the text itself remains vague when it comes to identification and description of the "other" people. In Ezra 9:11, the phrase peoples of the lands is used within the prayer of Ezra when he recounts the history of Israel, and thus it appears to refer to people who lived in the land before the Israelites conquered it. On the other hand, in Ezra 9:2, it is used to refer to the contemporaries of the golah. Thus, the same phrase refers to different eras. Nevertheless, it is undoubtedly employed to refer to "other" people, to characterize them and

20 See, for instance, Becking, "On the Identity of the 'Foreign Women' in Ezra 9-10," 31-43, and H. G. M. Williamson, "Welcome Home," in The Historian and the Bible: Essays in Honour of Lester L. Grabbe, ed. Philip R. Davies (New York: Bloomsbury, 2010), 113-123.

21 See, for instance, Bustenay Oded, "The Time of Zerubbabel vis-à-vis the Time of Ezra: Between 'Holy People' and 'Holy Seed,"' in Built by Wisdom, Established by Understanding: Essays on Biblical and Near Eastern Literature in Honor of Adele Berlin, ed. Maxine L. Grossman (Bethesda, MD: University Press of Maryland, 2013), 265. 
differentiate them from the golah people - that unlike the golah people they have abominations, that they are unclean. In that sense, the people referred to by the phrase still belong to the same, broad group of "other" people, though exact identities are not the same, even if they could be identified so.

The one piece of information the text does provide about the "other" people, peoples of the lands, is their enumeration in a list with other people who have abominations: "like those of the Canaanites, Hittites, Perizzites, Jebusites, Ammonites, Moabites, Egyptians, and Amorites" (Ezr 9:1, 11). From the use of the preposition "like" (kè), it is clear that the peoples of the lands are not equated with the nations listed but are, rather, only likened to some nations of the past. ${ }^{22}$ Moreover, there is no exact source of these nations appearing together in the Hebrew Bible. ${ }^{23}$ Evidently, this listing of nations is random and serves more to stereotype rather than to reference specific nations. As such, the phrase seems to be used more as a literary device to characterize the "other." The phrase peoples of the land/s would then refer to any or all non-golah people in a general sense, with no specific identification nationally or genealogically. ${ }^{24}$ Therefore, the antagonist "other" people could be anyone, any group of people other than the golah group who lived such lifestyles as those stereotyped nations and are unacceptable to the Yahwistic golah community.

\section{Foreign Women}

The choice of the term nokrî ("foreign," Ezr 10:2, 10, 11, 14, 17, 18, 44) gives the impression that the women are non-Israelites, as the term usually refers to someone "outside the family," someone not of the people

22 A. Philip Brown II, “The Problem of Mixed Marriages in Ezra 9-10," Bibliotheca sacra 162, no. 648 (October 2005): 447.

23 The first four nations and the last on the list (Canaanites, Hittites, Preizzites, Jebusites, Amorites) could have come from Deuteronomy 7:1, nations with which intermarriage is prohibited for fear of apostasy (Dt 7:3-4). The other two nations (Ammonites and Moabites) could have come from Deuteronomy 23:4 and referred to those who should not be admitted into their assembly. Williamson, Ezra, Nehemiah, 131.

24 In other appearances in the Hebrew Bible also, non-Israelites and non-Yahwists are often referenced in this way. In most cases, the peoples of the land/s is used to refer to people in the general sense: those people who worship other gods, in contrast to those who worship YHWH (peoples of the land in Es 8:17; Jo 4:24; Zep 3:20; Dt 28:10; $1 \mathrm{Kgs} 8: 43$; 53; $1 \mathrm{Chr}$ 5:25; 6:33; Ez 31:12; peoples of the lands in $2 \mathrm{Chr} 13: 9 ; 32: 13$ ). 
of Israel and coming from a distant land (1 Kgs 8:14; Dt 17:15). ${ }^{25}$ It refers to someone belonging to another family, clan, tribe, or nation. ${ }^{26}$ It thus seems that these women are not simply non-exiled Jews but real foreigners, that is, non-Israelites. Yet, the term also correlates with the peoples of the land- "foreign women from the peoples of the land" (10:2). That is, besides the absence of information to specify the exact identity of the women, the "foreign women" are also associated with the people of the land, a phrase that can include both non-Jews and non-exiled Jews. Therefore, in the book of Ezra there is no evidence to restrict "foreign women" exclusively to non-Jews and it is possible that the term "foreign women" is a literary designation to include any women who are non-golah, whether non-Jews or non-exiled Jews. ${ }^{27}$ In the narrative of Ezra 9-10, what is more problematic is not the exact identity of the women, that is, whether the women are real foreigners or not, but rather that they do not align with the golah community standards.

In sum, the "other" people could include anyone-non-exiled Jews or non-Israelites - who are not part of the protagonist golah community and who live abominable lifestyles unacceptable to the golah community. More critical to the golah community than their specific identity is that these "other" people practice abominations.

\section{Problem with the "Other" People}

The text states that the abominations of the peoples of the lands are like those of the nations of the Canaanites, the Hittites, the Perizzites, the Jebusites, the Ammonites, the Moabites, the Egyptians, and the Amorites

25 H. Ringgren, "nokrî," Theological Dictionary of the Old Testament, Vol. 9, ed. G. Johannes Botterweck, Heinz-Josef Fabry, and Helmer Ringgren (Grand Rapids: Eerdmans, 2019), 425-429.

26 The Dictionary of Classical Hebrew, Vol. 5 (Sheffield: Sheffield Academic, 1993), 694.

27 It may also be tempting to interpret the "foreign women" to be Samaritans, but in the book of Ezra vague identifications and descriptions of the "other" do not allow specific identification. I have argued elsewhere, in agreement with others, that there is no evidence to support the identification of antagonistic group/s in the books of Ezra-Nehemiah with Samaritans, since the schism between Jews and Samaritans is now commonly dated to a much later period, such as the Hasmonean period. Chingboi Guite Phaipi, "The First Encounter of the Golah and their 'Adversaries' (Ezra 4:1-5): Who Are the Adversaries, and On What Is the Adversity Based?," Journal of Hebrew Scriptures 20, no. 4 (2020): 21-22. 
(Ezr 9:1). A study of "abominations," particularly when used in reference to other nations, reveals it to be actions or lifestyles that are unacceptable to YHWH. Such abominable actions include both the cultic and ethical. For instance, the term refers to sexual immorality, child sacrifice, profaning God's name (Lv 18:26-30); divination, witchcraft, necromancy and such, which are regarded as practices of Canaanite nations (Dt 18:9-12; 20:17,18); idol worship (Dt 7:25,26; 12:29-31; 2 Kgs 21:1); worship of Baal (Jer 2:7). ${ }^{28}$ Thus, while it may not be possible to strictly narrow down "abominations" to a single list of specific actions in Ezra 9-10, the term would generally mean cultic actions such as idolatry and ethical actions such as sexual immorality. They are actions that are irreconcilable with YHWH, contrary to the will and character of YHWH; abominable acts are like taboos ethically and cultically. ${ }^{29}$ The peoples of the lands are then said to have lifestyles like those of the non-Yahwistic nations, and therefore the YHWH-worshiping golah community is to remain apart from them. In fact, the text itself refers to these peoples directly with their abominations - "the people of these abominations" (9:14).

Another noted problem with the peoples of the lands is that they are "unclean" (9:11). ${ }^{30}$ In the context of Ezra 9-10 the term for uncleanness, niddâ, refers to the deplorable state of the land because of the abominable lifestyles of those who inhabit it, which is unacceptable to the golah people who are set apart for YHWH. ${ }^{31}$ Thus, the term also denotes the difference

28 When in reference to Israelites also, the term has a similar connotation of cultic actions and ethical lifestyles. Such actions include sacrificing to other gods or idol worship (Jer 16:18-20; 44:4, 22,23; Dt 27:15; 32:16; 2 Kgs 16:3), profaning the sanctuary and marrying the daughter of a foreign god (Mal 2:11); sexual immorality, injustice, robbery, murder, idolatry (Ez 5:9; 7:3, 4, 8, 9; 14:16; 16:36, 50, 58; 18:12, 13; 22:11; 33:26); whoredom, sexual immorality, dishonesty (Dt 23:18,19; 24:4; 25:13-16); child sacrifice and idolatry (2 Kgs 16:3; 21:2-4,11).

29 Preuss, "Tôéb'âa," Theological Dictionary of the Old Testament, Vol. 15 (Grand Rapids: Eerdmans, 1974), 602.

30 The term could mean ceremonial uncleanness (such as menstruation, Ez 18:6; 22:10; 36:17; Lv 12:2; 15:19-25, taking one's brother's wife, Lv 20:21, or uncleanness of a corpse, Nm 19:9-21). The term could also be figurative, particularly in reference to idolatry (2 Chr 29:5; Zch 13:1; Ez 7:19-20).

31 The land is compared to a woman who becomes unclean, a niddâ, during and because of her menstruation. Erbele-Küster, studying the term particularly in Lv 15, argues that the term cannot be translated as menstruation in all cases. She argues that in Lv 15:19, niddâ would be a technical term for a cultic condition caused by blood 
between the golah and "others." Similarly, the term for "impurity" (țum'â) (9:11) would refer to impurity through ethical (such as sexual) and religious practices (such as idolatry) (Nm 5:19; Lv 16:16; Lv 18; Ez 22:13-15; 24:13$14 ; 36: 25,29) .{ }^{32}$ The golah community is not to imitate the unethical lifestyles of the peoples of the lands, or at least as the text accuses them to be. Unfortunately, however, the golah community has failed and accepted them into their community by marrying their women.

\section{Unfaithfulness of the Golah Community}

The golah community has acted unfaithfully by not keeping itself apart from the peoples of the lands and even marrying their women (Ezr 9:1-2). This unfaithfulness is also equated with breaking YHWH's commandments (mişwôt, Ezr 9:10, 14; 10:3).

The term for unfaithfulness, ma'al, indicates offense against God. While in some instances the term may express trespass against the holy temple (2 Chr 26:16-18; 28:19--25) or violation of oath taken in YHWH's name ( $\operatorname{Lv} 20: 3 ; 26: 15$; Is 57:15) or against other humans (Nm 5:6), the common denominator of ma'al is against God. ${ }^{33}$ That is, a ma'al is an act of disobedience to YHWH, whether or not the action itself takes different forms. Unfaithfulness could also lead to YHWH's wrath against the whole community even when it is committed by some individuals, as seen in Ezr 9-10, where some golah men's unfaithfulness is seen to affect the whole community. ${ }^{34}$ As such, the entire golah community should take stringent

flow lasting for seven days, and thus the words "her discharge being blood" indicates a physical phenomenon, while the term niddâ is more of a cultic description. Furthermore, the duration of blood flow is variable, while niddâ by definition lasts for seven days, that is, the period of exclusion from the sacred will last seven days regardless of the actual length of menstruation. Dorothea Erbele-Küster, Body, Gender and Purity in Leviticus 12 and 15 (London: Bloomsbury T \& T Clark, 2017), 120-121.

32 The terms "uncleanness" and "impurity" are rarely used of non-Israelites. Thus, searching for the implication of "uncleanness of the peoples of the land" from other biblical references does not help much.

33 Jacob Milgrom, "The Concept of Ma'al in the Bible and the Ancient Near East," Journal of the American Oriental Society 96, no. 2 (1976): 236-239.

34 In other appearances also, similar cases are observable. Achan's unfaithfulness brought God's wrath on the whole community (Jo 22:20), king Ahaz's unfaithfulness led to the subjugation of Judah ( $2 \mathrm{Chr} 28: 19)$, Israel will be sent into exile because of 
steps against any unfaithfulness to conserve their community as being a holy seed and a remnant - set apart from others for YHWH and to perpetuate to the future.

\section{The Resolution: Send Away Foreign Wives and THeir Children (EZRA 10:3-44)}

In order to repent for their unfaithfulness, the golah community resorts to sending away the foreign wives and their children (Ezr 10:3, 12). Ezra and the community leaders collect the names of all the men who had brought home foreign women (Ezr 10:16-44). Anyone who does not appear within three days would be separated from the community and their property would be confiscated (Ezr 10:8). This means that any men who fail to abide by the remedial measures of their unfaithfulness will be excommunicated from their community, making them equal in status with non-golah people, who are unacceptable to them $(9: 1 ; 10: 11)$. Anyone who does not appear to remedy the unfaithfulness of their community can no longer be a part of this group.

\section{Wrestling with the Resolution}

The stringent proposal to send away the foreign wives and their children in Ezra 9-10 has invited varied interpretations, only a few of which can be assessed briefly here. Some commentators, such as Oswald, attribute the "forced divorce" to political reasons, not to cultic reasons or a wish to preserve orthodoxy of faith, because, he argues, those who investigated the case are civil/political leaders (Ezr 10:8) and such terms as "assembly of exiles" imply an institutional or political body. ${ }^{35}$ In response to Oswald, the fact that the leaders are lay leaders does not necessarily make the case to be political. After all, even the cultic leaders are involved in this unfaithfulness (10:18). Also, even if the term "assembly of exiles" is to be understood as a political community, it does not completely dismiss the golah community from being cultic, as clearly seen in the narrative.

Others, such as Smith-Christopher, view through a sociological lens and contend that the only basis for Ezra's objection to the mixed marriage is

the king's unfaithfulness (Ez 17:19-21).

Oswald, "Foreign Marriages and Citizenship": 2-5. 
that the so-called foreigners are simply Jews who were not in exile. SmithChristopher adduces evidence for his argument from two points: (1) the presence of texts more lenient toward foreigners, such as Isaiah 60:1-5 and Ruth and Jonah, (2) the fact that the groups with which these "mixed" marriages are taking place are identified with old terms that have become stereotypically pejorative slurs for those ethnic groups who long have disappeared. ${ }^{36}$ Similarly, Eskenazi and Judd, by comparing the issue with modern Israeli haredi laws, identify the foreign wives in Ezra 9-10 as those who had not been exiled and thereby were appropriate marriage partners until Ezra appeared and introduced stringent laws. ${ }^{37}$ In regard to specific identifications, while it is quite possible that non-exiled Jews are among the "foreign" wives, there is not enough evidence to identify the "foreign" wives exclusively with non-exiled Jews. As argued earlier, the Hebrew term for "foreign," nokrî, usually refers to non-Israelites, and, more importantly, the text is less interested in specific identity and more in how these foreign women are abominable. From the unspecific nature and in the perspective of the narrative, then, "foreign" can actually include any non-golah people. Still others, such as Dor ${ }^{38}$ and Japhet, ${ }^{39}$ see the passage rather as an indication of acceptance, not denial, of the foreign wives. Their basic

36 Smith-Christopher, “The Mixed Marriage Crisis,” 257.

37 Eskenazi and Judd, "Marriage to a Stranger," 266-285.

38 Through literary-textual analysis Dor notes that the text records only a publication of the list (Ezr 10) without any mention or indication that the wives and children were actually sent away and thereby concludes that the separation events were "merely symbolic ceremonies or rituals that were meant to enable accepting of outsiders into the community.” Yonina Dor, “The Rite of Separation,” 174-186.

39 Japhet argues that when women are of inferior status, the children absorb the fate of their mother, not their father. Japhet notes that Sarah was legally able to demand that Abraham send Hagar away because of Hagar's Egyptian origin and her status as a slave-woman (Gn 21:9-23). Ishmael is identified from his mother Hagar as "the son of the slave-woman" (Gn 21:10,13). Also, the sons of Abraham with his wife Keturah are identified as "sons of the concubine" (Gn 25:6). Furthermore, the laws regarding Hebrew slaves dictate that if the master gives the slave a wife, her children take their status from her (not their father), and even when the slave goes free, the wife and children would still belong to the master (Ex 21:3-4). Japhet finds a common denominator in these three cases - a slave, a concubine, and a possession of the master-and thus all these women are of inferior status and their children take the fate of their mothers. Japhet then argues that these three similar cases provide the analogous legal framework for the proposed solution in Ezra 9-10 (10:2) and argues that a conventional divorce procedure is not necessary because the foreign women 
argument is that the sending away of foreign wives in Ezra 9-10 is "on paper" and never carried out; thus the events become symbolic ceremonies for accepting them or elevating the status of those who were simply "secondary wives" earlier because of their foreign status. While this argument is attractive to modern minds, there is not enough evidence in Ezra. While from the corrupted Hebrew of Ezra 10:44, which does not mention "sending away," it can fairly be questioned whether the wives and children were actually sent away, there is no evidence in the text to imply the event as an acceptance-event.

More recently, Southwood, taking an anthropological approach, identifies Ezra 9-10 as reflecting a return migration group trying to protect their ethnic identity. ${ }^{40}$ Again, as she herself asserts, terms such as "ethnicity" can be fluid and confusing, so it is hard to apply it strictly to the golah community in the book of Ezra. Saysell, by reading the passage as Christian Scripture, argues that the solution is not so harsh considering what is required by the pentateuchal hêrem laws (Ex 22:19; Lv 27:29; Dt 13:13-18; 20:16-18; Jo 10:28, 37, 39). ${ }^{41}$ Yet, as Saysell herself notes, the situation in Ezra 9-10 is different in that while in the herem law the person bringing an idol into the community would also be banned, in Ezra 9-10, the men who brought the foreign women are not put away; more importantly, a different term, bādal, is used in Ezra, not hēerem.

are of inferior status and counted as "secondary wives." Thus, for Japhet, the event of sending away the foreign wives in Ezra 9-10 is an innovation for an unprecedented situation in which the foreign women are elevated with slave women, and it becomes one of the factors that facilitated the idea and practice of conversion. Sara Japhet, "The Expulsion of the Foreign Women," 100, 151-161.

40 Katherine Southwood provides a very helpful comprehensive survey of the research literature on Ezra 9-10. Some other proposed explanations for the strong disapproval of intermarriage in Ezra 9-10 include fear of religious syncretism, inheritance and land property, the threat of female inheritance, land rights in connection with Persian administration, class and economic class competition. In response to these arguments, Southwood rightly observes that there is no mention of apostasy or the possibility of religious conversion in the text. The text is also silent on land ownership or inheritance, and it is not possible to know the real status of the people in the international context of Persian imperial power. For a detailed survey and discussion of the arguments and rationales, see Southwood, Ethnicity and the Mixed Marriage, 75-122.

41 Saysell, According to the Law, 58-80. 
Thus, while arguments such as those stated above are appealing and have their own merits, there is just not enough evidence, particularly in the text. More significantly, the text does not pinpoint only women or foreign women but commands the whole golah community to keep themselves apart from the peoples of the land/s (Ezr 9:1; 10:2, 3, 11). Thus, the solution has to do not just with foreign wives, but it should have something to do with all "other" people. In addition, while the proposed solution is said to be "according to the law," there is no known pentateuchal law that commands the divorce of a foreign wife nor what to do if someone failed to keep the command. For instance, in Deuteronomy 7:1-4 Israelites are told not intermarry with the Canaanite nations because they will turn them to apostasy, but it is not a general command against all foreign women, and there is also no mention of how to respond if someone fails to obey the command. The evoking of the law in Ezra 9-10 could rather be an interpretation of a general law or teachings or tradition, ${ }^{42}$ and attempts to locate a specific law have yielded nothing. Thus the resolution to send away foreign wives is to be interpreted from within the narrative.

\section{The Solution in Perspective of the NarRative}

The situation in Ezra 9-10 and the way the golah community handles the situation they found themselves in are unprecedented and sound quite radical, but they can be made sense of when considered within the perspective of the larger narrative. The golah community's understanding of their situation and their self-perception of their own community are the determining factors in how they handle the situation.

The narrative of Ezra 9-10 presents the golah community as a cultic community, a group set apart for YHWH ("holy seed," Ezr 9:2) and a remnant (Ezr 9:8, 13, 14, 15) to continue pre-exilic Israel into the future. From these two staunch self-understandings derive the main criteria to be a part of the community - to maintain being a holy seed and to fulfill being a remnant. Therefore, keeping oneself apart from "others" whose lifestyles are unacceptable to YHWH and the golah community becomes the way to fulfill their responsibilities. "Other" people, designated by people/s of the lands and "foreign women" who have abominations unacceptable to the

42 Fried, Ezra, 395. 
Yahwistic golah community, cannot be a part of the community and would have to be removed from their community. In fact, even those already a part of the golah community run the risk of being ejected if they fail to remain apart and intermarry "other" women (Ezr 10:8).

Mention must also be made of the ending of the narrative, which is corrupted and literally reads: "And there were some of them (masculine) women and they (masculine) had children" (10:44). Thus it cannot be known whether the foreign women and their children were actually sent away. We have no clue of what happens next with the golah community. In addition, only the priests are proved to make a pledge to send away their foreign women with no indication of whether they actually followed through (10:19), and no laymen pledge to send away their foreign wives and children. What is clear, however, is that the golah community has a strong perception of themselves as a cultic community with a God-given responsibility to perpetuate itself, and in sending unacceptable people away from their community, or attempting to do so, they intend to maintain their perceived identity and responsibility. From a literary analysis it can be seen that being a golah community or an "other" is based primarily on cultic grounds more than anything else. An "other" can then be a nonexiled Jew or a non-Jew. For the golah community, then, there are only two kinds of people - the golah and all/any non-golah who do not align to their cultic ways.

\section{A Minority Tribal's Personal Reflection on the Passage}

A comprehensive hermeneutical reflection is beyond the scope of this paper. Nevertheless, in briefly considering the Ezra 9-10 narrative's negative attitudes toward the "other" in its relevance for today, there are different options. For example, we could avoid reading it, since there are other books in the canon. Or we could read only the parts that are inspiring while ignoring the difficult parts. Or we could simply follow the example of the golah community and apply it to today. But, none of these options is favorable if a community is to be faithful to Scripture. I would like to propose that we read the entire narrative and wrestle more particularly and diligently with the difficult parts before interpreting it and applying it to our contemporary context. 
Coming from a minority Christian tribe, the Paite,${ }^{43}$ in northeast India, there are some ways our people would resonate with the alterity discourse of the golah community in our particular situation. One thing I observe from the narrative is that the golah community's view toward the "other" largely comes from their perception of themselves. That is, their strong self-perception as the ones set apart for YHWH ("holy seed") and saved as a "remnant" after the exile to continue Israel into the future challenges them to be cautious to keep themselves apart from "other" people. As a minority group, most Paite people feel a similar need to be distinct and to preserve our distinctiveness as a Paite Christian tribe. Marrying someone from another tribe or ethnic group is not encouraged. And even if one does so, it is relatively easier to be accepted if one is marrying another Christian-and most preferably one of the same denomination-rather than a non-Christian, which is highly disapproved of and, in certain cases, could even lead to being (virtually) disowned by family or the larger Paite community. And, as with the golah community, the Paites' view of "other" people, which discourages intermarriage, does not seem necessarily to stem primarily from a negative view of "other" people but, rather, from their own view of their distinctiveness as a Paite Christian tribe and the need to preserve that identity. It is as if by intermarrying with another race or religion, our "Paite-ness" or Christianity would be diminished or extinct.

Having said that, should we follow the example of the golah community, particularly the way they dealt with their foreign wives in Ezra 9-10? The path the golah community took is unimaginable from a modern multicultural perspective. Certainly, it would have been difficult in the biblical context too, as seen, for instance, in the sending away of Hagarwhen Hagar and the child suffered, Abraham himself suffered too (Gn 21:11, 14-16). Did the path taken in Ezra 9-10 end well for the golah community and for the women and children who were sent away? Would that path have solved the problem the golah community encountered?

In fact, as seen in the analysis of the text, it is not even explicitly asserted whether the wives and their children were actually sent away. The narrative

43 The Paite (Zomi) tribe is one of the tribes of India that mainly inhabits the southern part of the state of Manipur, although it has now spread all over the country and other parts of the world. The Paite tribe as a community embraced Christianity when Welsh missionaries brought the Gospel to us in 1910, and since then, all Paites are Christians, at least nominally. 
ends confusingly, stating how some golah men married foreign women and some even had children (10:44b), and we have no account of the situation of the golah community or of the foreign wives after that. At least it can be said that such actions were not repeated, or at least not mentioned in the Bible in either the Old Testament or the New Testament. Even Nehemiah did not send people away, although he used physical violence to object to and disapprove of such intermarriage (Neh 13:23-28). Furthermore, interpreting it as a "mass divorce" might not have been the case, since it seems to have affected a small percentage of the community-about 111 people out of approximately 30,000 returned exiles: 0.58 percent of the clergy and about 0.67 percent of the lay people. ${ }^{44}$ It is important to study the whole narrative to understand the whole picture.

Difficult texts such as Ezra 9-10 should be read and engaged with, not quickly dismissed or even judged as "negative." But with diligence and creativity, and prayerfully, they should be studied before being implemented in our own contexts. The golah community itself was trying to apply the Scripture ("law") in their context (Ezra 9:6-15; 10:3). Yet, claiming and accepting the authority of Scripture does not necessarily oblige us to apply the actions of the community in the text to our communities today. Needless to say, while there may be outward similarities in the exclusivist attitudes of the golah community of the book of Ezra and the Paite tribe today, the contexts are quite different. Therefore, a careful study of the communities of both the text and our own today is a prerequisite before the measures are applied. As such, the best we can do is to engage with the text, wholly and faithfully. We obviously need better and more concrete ways to relate with the "other" in our context, whether in the Paite tribal Christian context or in the larger global Christian context; however, what that means is beyond the scope of this work.

\section{About author}

Chingboi Guite PHAIPI (PhD, Lutheran School of Theology at Chicago) is an adjunct faculty member at McCormick Theological Seminary, Chicago.

44 David J. Shepherd and Christopher J. H. Wright, Ezra and Nehemiah (Grand Rapids: Eerdmans, 2018), 149; Ralph W. Klein, Ezra and Nehemiah, New Interpreter's Bible 3 (Nashville: Abingdon, 1999), 745-746. 